Image of the month

\title{
Double cortex syndrome - A rare cause of refractory epilepsy
}

\author{
Saurabh Bansal, Manoj Goyal*, Manish Modi, Chirag Ahuja \\ Department of Neurology, Postgraduate Institute of Medical Education and Research, Chandigarh 160012, India
}

\section{A R T I C L E I N F O}

\section{Article history:}

Received 1 August 2016

Accepted 27 August 2016

Available online 17 September 2016
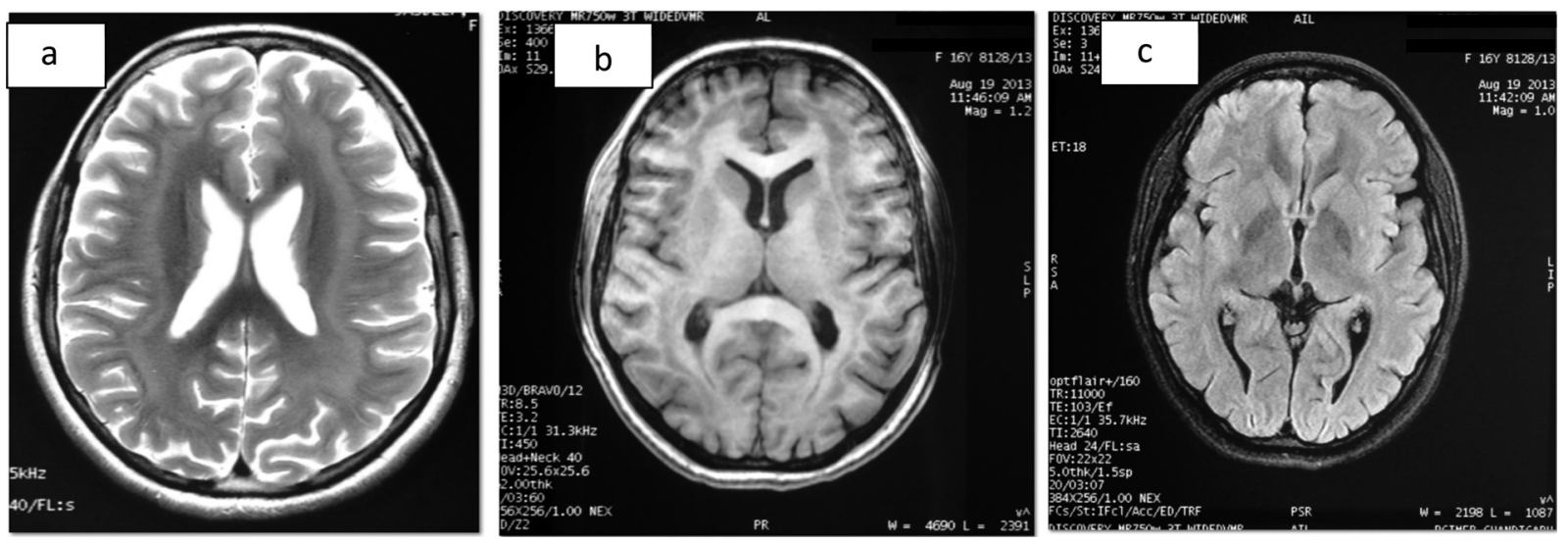

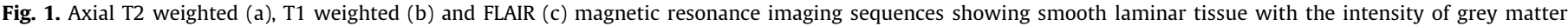
interspersed between cortical grey matter and subcortical white matter, producing the classic picture of double cortex.

Miss A, a 16-year-old girl presented with dyscognitive focal (daily) as well as generalized seizures (once or twice a month) for past 12 years with poor scholastic performance. Magnetic resonance imaging (MRI) of brain revealed diffuse subcortical band heterotopia or double cortex syndrome (DCS) (Fig. 1). She was treated with carbamazepine $(30 \mathrm{mg} / \mathrm{kg}$ ) and levetiracetam $(40 \mathrm{mg} / \mathrm{kg}$ ) with decrease in frequency of focal seizure to once every two to three months and amelioration of generalized seizures. DCS usually occurs due to mutations involving doublecortin (DCX) gene located on $\mathrm{X}$ chromosome and almost exclusively occurs in females. ${ }^{1}$ This gene encodes a microtubule associated protein essential for neuronal migration during embryogenesis. Most common presentation includes cognitive maldevelopment and seizures which usually start in first decade.
The severity of symptoms usually correlates with size of the band. ${ }^{2}$ Recognition of the classic MRI pattern is important for prognostification, proper treatment as well as rehabilitation of these patients.

\section{Conflicts of interest}

The authors have none to declare.

\section{References}

1. Kaur S, Ghuman MS, Devarajan LJ. A pediatric epilepsy classic: "Double Cortex" syndrome. J Paeditr Neurosci. 2015;10(2):125-126.

2. Bahi-Buisson N, Souville I, Fourniol FJ, et al. New insights into genotype-phenotype correlations for the doublecortin-related lissencephaly spectrum. Brain. 2013;136:223-244.

\footnotetext{
* Corresponding author.

E-mail address: goyal_mk@yahoo.com (M. Goyal).
} 